\title{
PENGARUH INTELEGENSI, MOTIVASI BELAJAR, DAN MINAT BELAJAR TERHADAP HASIL BELAJAR EKONOMI KELAS XI IPS DI SMA NEGERI KOTA MOJOKERTO
}

\author{
Jenitta Vaulina Puspita Sari, Universitas Negeri Surabaya \\ jenittavaulina@gmail.com
}

\begin{abstract}
ABSTRAK
Penelitian ini bertujuan untuk menganalisis pengaruh intelegensi, motivasi belajar, dan minat belajar secara parsial dan simultan terhadap hasil belajar ekonomi kelas XI IPS di SMA Negeri Kota Mojokerto. Sampel dalam penelitian adalah 184 peserta didik kelas XI IPS. Penelitian ini memakai pendekatan kuantitatif. Data dianalisis dengan menggunakan analisis regresi linier berganda. Hasil penelitian ini menunjukkan bahwa (1) Intelegensi berpengaruh terhadap hasil belajar ekonomi kelas XI IPS di SMA Negeri Kota Mojokerto; (2) Motivasi belajar berpengaruh terhadap hasil belajar ekonomi kelas XI IPS di SMA Negeri Kota Mojokerto; (3) Minat belajar berpengaruh terhadap hasil belajar ekonomi kelas XI IPS di SMA Negeri Kota Mojokerto; dan (4) Intelegensi, motivasi belajar, dan minat belajar secara bersama-sama berpengaruh signifikan terhadap hasil belajar ekonomi kelas XI IPS di SMA Negeri Kota Mojokerto.Berdasarkan hasil penelitian, dapat disimpulkan bahwa intelegensi, motivasi belajar, dan minat belajar merupakan faktor yang efektif mempengaruhi hasil belajar peserta didik, namun faktor-faktor lain yang mempengaruhi hasil belajar, seperti faktor fisiologis, psikologis, keluarga, sekolah, dan masyarakat juga harus diperhatikan untuk mewujudkan hasil belajar ekonomi yang optimal.
\end{abstract}

Kata Kunci: Intelegensi, motivasi belajar, minat belajar, hasil belajar ekonomi

\section{ABSTRACT}

This study aimed to analyze the effect of intelligence, learning motivation, and learning interest, partially and simultaneously on learning outcomes of economics in grade XI Social Class SMA Negeri Kota Mojokerto. The sample was 184 students in grade XI social class. The study used a quantitative approach. Data were analyzed using multiple linear regression. The results of this study indicate that (1) there is significant effect between intelligence on learning outcomes of economics in grade XI Social Class SMA Negeri Kota Mojokerto; (2) there is significant effect between learning motivation on learning outcomes of economics in grade XI Social Class SMA Negeri Kota Mojokerto; (3) there is significant effect between learning interest on learning outcomes of economics in grade XI Social Class SMA Negeri Kota Mojokerto; and (4) there is simultaneous effect between intelligence, learning motivation, and learning interest on learning outcomes of economics in grade XI Social Class SMA Negeri Kota Mojokerto. Based on the results, it can be concluded that intelligence, learning motivation, and learning interest are factors that effectively effect on the learning outcomes of students, but the other factors 
that affect learning outcomes, such as physiological factors, psychological, family, school, and society should also be considered to achieve optimal learning outcomes of economics.

Keywords: Intelligence, learning motivation, learning interest, learning achievement of economi.

\section{PENDAHULUAN}

Pendidikan merupakan sarana terpenting untuk mewujudkan kemajuan bangsa dan negara, hal ini dikarenakan bahwa pendidikan merupakan proses budaya yang bertujuan untuk meningkatkan harkat dan martabat manusia. Pendidikan itu sendiri berlaku seumur hidup dan dilakukan dalam lingkungan keluarga, pendidikan formal sekolah, dan masyarakat, oleh sebab itu pendidikan merupakan tanggung jawab bersama antara keluarga, masyarakat, dan negara. Menurut Undang-Undang Republik Indonesia nomor 20 tahun 2003 tentang Sistem Pendidikan Nasional pasal 1 menyebutkan bahwa Pendidikan adalah usaha sadar dan terencana untuk mewujudkan suasana belajar dan proses pembelajaran agar peserta didik secara aktif mengembangkan potensi dirinya sehingga memiliki kekuatan spiritual keagamaan, pengendalian diri, kepribadian, kecerdasan, akhlak mulia, serta keterampilan yang diperlukan dirinya, masyarakat, bangsa dan negara. Untuk mencapai tujuan pendidikan sebagaimana yang diharapkan dalam UndangUndang maka sesuai dengan Peraturan Menteri Pendidikan Nasional Nomor 19 Tahun 2007 tentang Standar Pengelolaan Pendidikan Oleh Satuan Pendidikan Dasar dan Menengah dijelaskan bahwa unsur-unsur yang berperan penting dalam pencapaian tujuan pendidikan salah satunya yaitu proses belajar mengajar dengan hasil belajar sebagai salah satu output mutu pendidikan yang merupakan tujuan dari pendidikan nasional, sehingga dalam hal ini pencapaian hasil belajar peserta didik yang tinggi merupakan harapan berbagai pihak termasuk peserta didik itu sendiri, guru, sekolah, masyarakat, dan pemerintah.

Hasil belajar ekonomi merupakan salah satu indikator untuk mengetahui keberhasilan belajar pada mata pelajaran ekonomi, hal ini seperti yang diungkapan oleh Sudjana (2013) bahwa hasil belajar digunakan untuk mengetahui sejauh mana tindakan atau kegiatan belajar mengajar dapat mencapai tujuan-tujuan instruksional yang dicapai dan dikuasai oleh peserta didik. Dengan hasil belajar yang baik diharapkan mampu menggambarkan kualitas pendidikan yang baik. Dalam usaha untuk mencapai hasil belajar yang optimal dipengaruhi oleh faktor internal dan faktor eksternal, dimana menurut Slameto (2010) faktor internal yaitu faktor yang ada dalam diri individu yang sedang belajar dibagi menjadi 2 bagian yaitu faktor fisiologis (jasmaniah) dan faktor psikologis yang meliputi intelegensi, perhatian, minat, bakat, motivasi, kematangan dan kesiapan. Sementara faktor eksternal merupakan faktor yang berasal dari luar individu dibedakan menjadi 3 bagian yaitu: faktor keluarga, faktor sekolah, dan faktor masyarakat.

Berdasarkan hasil observasi awal, diketahui bahwa hasil belajar ekonomi peserta didik kelas XI IPS di SMA Negeri Kota Mojokerto tahun pelajaran 2015-2016 masih rendah. Hasil belajar tersebut dilihat melalui nilai 
ulangan akhir semester satu (semester ganjil) dimana sekitar 45,43\% dari total 339 peserta didik yakni 154 peserta didik kelas XI IPS SMA Negeri Kota Mojokerto nilai ulangan akhir semester satunya belum memenuhi standart ketuntasan minimal yang ditetapkan oleh SMA Negeri Kota Mojokerto yaitu nilai 75, sehingga peserta didik tersebut masih harus mengikuti ulangan perbaikan nilai atau Remedial. Tingkat pemahaman ekonomi kurang memuaskan apabila peserta didik belum mampu memenuhi kriteria ketuntasan minimum (KKM) yang telah ditentukan yaitu 75 .

Sepeti yang telah dikemukakan sebelumnya bahwa hasil belajar dipengaruhi oleh beberapa faktor yaitu internal dan eksternal, dan di antara kedua faktor tersebut Clark (dalam Sudjana, 2013) menyatakan bahwa faktor internal yang meliputi Intelegensi, motivasi, minat, kematangan, dan kesiapan lebih dominan dan menentukan $70 \%$ dari hasil belajar dibandingkan dengan faktor eksternal yang meliputi sekolah, keluarga, dan masyarakat yang hanya berkontribusi $30 \%$ dalam mempengaruhi hasil belajar, sehingga peneliti melakukan observasi lanjutan dengan melakukan wawancara kepada guru ekonomi kelas XI IPS di SMA Negeri Kota Mojokerto untuk menemukan faktor internal apa yang secara khusus mempengaruhi hasil belajar ekonomi peserta didik kelas XI IPS di SMA Negeri Kota Mojokerto, karena menurut Wayan (2008) salah satu upaya untuk mengoptimalkan hasil belajar peserta didik adalah dengan mengenali serta meneliti faktor yang mempengaruhinya sehingga nantinya dapat menjadi referensi bagi guru dan peseta didik untuk meningkatkan hasil belajar.

SMA Negeri di Kota Mojokerto terdiri dari 3 sekolah yaitu: SMA Negeri 1 Kota Mojokerto, SMA Negeri 2 Kota Mojokerto, dan SMA Negeri 3 Kota Mojokerto merupakan sekolah yang memiliki grade tinggi di Kota Mojokerto, hal ini dapat dibuktikan sebagai berikut: 1)banyaknya calon peserta didik baru yang setiap tahunnya berlomba-lomba untuk dapat diterima dan masuk disalah satu SMA Negeri ini melalui sistem seleksi Penerimaan Peserta Didik Baru (PPDB) baik melalui jalur prestasi akademik maupun jalur prestasi non akademik; 2)pelaksanaan sistem seleksi Penerimaan Peserta Didik Baru (PPDB) SMA Negeri di Kota Mojokerto diselenggarakan secara online terpusat sehingga hasil yang didapatkan transparan dan bisa dipertanggung jawabkan; 3)terdapat 8 SMP Negeri di Kota Mojokerto dan SMP lainnya disekitar Kota Mojokerto, sehingga peserta didik yang diterima di SMA Negeri di Kota Mojokerto merupakan peserta didik pilihan yang telah memenuhi standart yang ditetapkan oleh Pemerintah Kota Mojokerto; 4)berdasarkan sistem seleksi Penerimaan Peserta Didik Baru (PPDB) tersebut maka SMA Negeri di Kota Mojokerto dapat menjaring peserta didik yang berprestasi, terbaik, dan memiliki intelegensi yang tinggi.

Anastasi \& Urbani (2007) menyatakan bahwa faktor intelegensi peserta didik merupakan komponen kognitif yang penting dalam mempengaruhi keberhasilan peserta didik dalam bidang akademis, meskipun menurut Azwar (2008) penentu keberhasilan peserta didik dalam akademisnya tidak hanya dapat dilihat dari aspek intelegensi saja. Sesuai dengan penelitian Ijaz (2012) yang mempelajari hubungan antara intelegensi dikalangan peserta didik maka diperoleh hasil bahwa faktor Intelegensi mempunyai pengaruh signifikan terhadap hasil belajar, oleh karena itu untuk mencapai hasil belajar 
ekonomi yang optimal diduga dipengaruhi oleh faktor intelegensi. Tes intelegensi di SMA Negeri Kota Mojokerto dilaksanakan di awal tahun ajaran baru, namun hasil tes intelegensi tersebut hanya digunakan sebagai penentu penjurusan program studi IPA, IPS, dan Bahasa sehingga tidak ada umpan balik secara langsung bagi peserta didik dalam kaitannya dengan hasil belajar, sehingga peneliti ingin mengetahui pengaruh faktor intelegensi terhadap hasil belajar peserta didik. Berdasarkan hasil tes IQ dapat diketahui bahwa rata-rata intelegensi peserta didik di SMA Negeri 2 Kota mojokerto merupakan yang tertinggi yaitu 109,46 dibandingkan dengan SMA Negeri 3 yang menempati urutan kedua yaitu 109,02 dan SMA Negeri 1 yang menempati urutan ketika yaitu 107,08. Bila hasil rata-rata tes IQ tersebut dikaitkan dengan tingkat intelegensi menurut skala wechler, makaintelegensi peserta didik kelas XI SMA Negeri Kota Mojokerto tahun pelajaran 2015-2016 masuk dalam kategori rata-rata normal atau average.

Keberhasilan pada diri peserta didik itu bergantung tidak hanya pada kecemerlangan otak atau peserta didik yang mempunyai intelegensi tinggi namun karena kuatnya motivasi belajar juga penting dalam menentukan keberhasilanpeserta didik, menurut Slameto (2010) seringkali peserta didik yang tergolong cerdas atau memiliki intelegensi tinggi akan tampak bodoh karena tidak memiliki motivasi belajar untuk mencapai hasil belajar sebaik mungkin, hal ini menunjukkan bahwa seorang peserta didik yang cerdas apabila memiliki motivasi belajar yang rendah maka dia tidak akan mencapai hasil belajar atau prestasi akademik yang baik, namun sebaliknya jika seorang peserta didik yang kurang cerdas tetapi memiliki motivasi belajar yang tinggi untuk belajar, maka dia akan mencapai hasil belajar atau prestasi akademik yang baik. Uno (2011) menjelaskan bahwa motivasi belajar dapat diartikan sebagai suatu dorongan atau penggerak yang ada didalam diri peserta didik yang menimbulkan kegiatan belajar, sehingga tujuan yang dikehendaki peserta didik dapat tercapai. Motivasi belajar tidak dapat diamati secara langsung akan tetapi dapat diinterpretasikan dalam tingkah lakunya, berupa rangsangan dorongan,atau pembangkit tenaga munculnya suatu tingkah laku tertentu. Berdasarkan hasil wawancara pada observasi lanjutan dengan guru ekonomi kelas XI IPS di SMA Negeri Kota Mojokerto diketahui bahwa motivasi yang dimiliki peserta didik kelas XI IPS di SMA Negeri Kota Mojokerto masih kurang. Hal ini dapat dilihat dari peserta didik yang terlambat datang kesekolah, kurang semangat saat mengikuti pembelajaran dikelas, kurang memiliki sikap kemandirian, dan masih ada peserta didik yang membolos saat kegiatan belajar mengajar ekonomi berlangsung. Jika dilihat secara seksama berdasarkan indikator motivasi belajar maka dapat disimpulkan bahwa motivasi belajar ekonomi peserta didik di SMA Negeri 3 Kota mojokerto adalah yang terbaik dibandingkan dengan SMA Negeri 1 dan SMA Negeri 2, hal ini dapat dilihat dari kehadiran peserta didik yang selalu tepat waktu dalam mengikuti jam pelajaran ekonomi, dibandingkan dengan peserta didik di SMA Negeri 1 dan SMA Negeri 2.

Ketika dikaitkan dengan aktivitas belajar, minat belajar merupakan salah satu alat motivasi atau dasar bagi peserta didik untuk melakukan aktivitas belajar. Tanpa adanya minat dalam diri peserta didik terhadap hal yang akan dipelajari, maka peserta didik akan ragu-ragu untuk belajar sehingga tidak 
menghasilkan hasil belajar yang optimal atau sepertinya yang diinginkan. Menurut Safari (2005) minat belajar merupakan pilihan kesenangan dalam melakukan kegiatan dan dapat membangkitkan gairah seseorang untuk memenuhi kesediaannya dalam belajar, pendapat tersebut didukung oleh Slameto (2010) yang menyatakan bahwa minat belajar merupakan suatu rasa lebih suka dan rasa ketertarikan pada suatu alat atau aktifitas belajar tanpa ada yang menyuruh. SMA Negeri di Kota Mojokerto menjuruskan peserta didik ke program studi IPA, IPS, dan Bahasa sesuai dengan minatnya, namun berdasakan hasil wawancara mengacu pada indikator minat belajar dengan guru mata pelajaran ekonomi diketahui bahwa ternyata pada saat proses pembelajaran peserta didik cenderung tidak mendengarkan penjelasan yang disampaikan oleh guru, peserta didik memilih untuk mengobrol dengan teman sebangkunya dibanding mendengarkan penjelasan guru, selain itu peserta didik juga jarang bertanya kepada guru tentang pelajaran ekonomi baik saat di kelas maupun di luar kelas. Hal ini didukung oleh hasil wawancara dengan beberapa peserta didik dimana peserta didik beranggapan bahwa pelajaran ekonomi merupakan pelajaran yang sulit untuk dipahami. Peserta didik malas mengikuti pelajaran tersebut, yang artinya memiliki minat belajar yang rendah, mengakibatkan hasil belajar yang diperoleh tidak mencapai KKM. Berdasarkan indikator-indikator yang mempengaruhi minat belajar nampak bahwa minat belajar di SMA Negeri 1 Kota Mojokerto lebih baik bila dibandingkan dengan SMA Negeri 2 dan SMA Negeri 3.Berdasarkan latar belakang masalah yang telah diuraikan di atas, penelitian ini membahas tentang Pengaruh Intelegensi, Motivasi Belajar, dan Minat Belajar Terhadap Hasil Belajar Ekonomi Kelas XI IPS di SMA Negeri Kota Mojokerto.

\section{METODE PENELITIAN}

Penelitian ini memakai pendekatan kuantitatif, dimana pendekatan kuantitatif dipilih karena menurut Kasiram (2008) yang menyatakan bahwa penelitian kuantitatif adalah suatu proses menemukan pengetahuan yang menggunakan data berupa angka sebagai alat menganalisis keterangan mengenai apa yang ingin diketahui, berdasarkan rumusan tujuan yang telah ditetapkan sebelumnya maka penelilian ini termasuk penelitian terapan. Penelitian terapan menurut Gay (dalam Sugiyono,2013) mengungkapkan bahwa penelitian terapan dilakukan dengan tujuan menerapkan, menguji, menganalisis, dan mengevaluasi kemampuan suatu teori yang diterapkan dalam memecahkakn masalah-masalah praktis. Sedangkan bila ditinjau berdasarkan metode yang digunakan dalam penelitian ini adalah penelitian kausal asosiatif (causal asosiatif research) yang dilakukan terhadap data yang dikumpulkan setelah terjadinya suatu peristiwa, maka dapat disimpulkan bahwa dengan menggunakan penelitian asosiatif dapat diketahui hubungan antara dua variabel atau lebih yang dapat menjelaskan gejala, yaitu menguji pengaruh Intelegensi $\left(\mathrm{X}_{1}\right)$, Motivasi Belajar $\left(\mathrm{X}_{2}\right)$, dan Minat Belajar $\left(\mathrm{X}_{3}\right)$ terhadap Hasil Belajar Ekonomi(Y). 
Tabel 1

Definisi Operasional Variabel

\begin{tabular}{|c|c|c|}
\hline Variabel & Konsep Variabel & Indikator \\
\hline $\begin{array}{l}\text { Intelegens } \\
\left.\text { i ( } X_{1}\right) \\
\text { Azwar } \\
(2008)\end{array}$ & $\begin{array}{l}\text { Intelegensi merupakan } \\
\text { kemampuan individu dalam } \\
\text { mendayagunakan potensi yang } \\
\text { ada pada dirinya. }\end{array}$ & $\begin{array}{l}\text { 1) Pemahaman; } \\
\text { 2) Penalaran; } \\
\text { 3) Kemampuan berhitung; } \\
\text { 4) Kemampuan mekanik; } \\
\text { 5) Logika abstrak; } \\
\text { 6) Logika verbal. }\end{array}$ \\
\hline $\begin{array}{c}\text { Motivasi } \\
\text { Belajar } \\
\left(\mathrm{X}_{2}\right) \\
\text { Uno } \\
(2011)\end{array}$ & $\begin{array}{l}\text { Motivasi belajar merupakan } \\
\text { suatu semangat yang berasal } \\
\text { dari dalam diri peserta didik } \\
\text { dalam mengikuti pembelajaran } \\
\text { di kelas guna mencapai tujuan } \\
\text { yang telah peserta didik } \\
\text { harapkan sebelumnya yaitu } \\
\text { memperoleh nilai baik. }\end{array}$ & $\begin{array}{l}\text { 1) Adanya hasrat dan keinginan berhasil; } \\
\text { 2) Dorongan dan kebutuhan dalam } \\
\text { belajar; } \\
\text { 3) Harapan dan cita-cita masa depan; } \\
\text { 4) Adanya penghargaan dalam belajar; } \\
\text { 5) Adanya kegiatan yang menarik dalam } \\
\text { kegiatan belajar; } \\
\text { 6) Lingkungan belajar yang kondusif. }\end{array}$ \\
\hline $\begin{array}{c}\text { Minat } \\
\text { Belajar }\left(\mathrm{X}_{3}\right) \\
\text { Slameto } \\
(2010)\end{array}$ & $\begin{array}{l}\text { Minat belajar merupakan suatu } \\
\text { rasa lebih suka dan rasa } \\
\text { ketertarikan pada suatu hal atau } \\
\text { aktifitas tanpa ada yang } \\
\text { menyuruh dan dapat } \\
\text { membangkitkan gairah peserta } \\
\text { didik untuk memenuhi } \\
\text { kesediaannya dalam belajar. }\end{array}$ & $\begin{array}{l}\text { 1) Perasaan senang; } \\
\text { 2) Perhatian dalam belajar; } \\
\text { 3) Ketertarikan; } \\
\text { 4) Kemauan untuk belajar; } \\
\text { 5) Relevansi (Manfaat dan fungsi mata } \\
\text { pelajaran). }\end{array}$ \\
\hline $\begin{array}{c}\text { Hasil } \\
\text { Belajar (Y) } \\
\text { Sudjana } \\
(2013)\end{array}$ & $\begin{array}{l}\text { Hasil belajar merupakan } \\
\text { sesuatu yang diperoleh peserta } \\
\text { didik dari suatu proses usaha } \\
\text { dalam menguasai pengetahuan } \\
\text { dan kecakapan dasar setelah } \\
\text { melakukan kegiatan belajar. }\end{array}$ & $\begin{array}{l}\text { Domain kognitif meliputi: } \\
\text { 1) Tingkatan hafalan; } \\
\text { 2) Tingkatan pemahaman; } \\
\text { 3) Tingkatan aplikasi; } \\
\text { 4) Tingkatan analisis; } \\
\text { 5) Tingkatan sintesis; } \\
\text { 6) Tingkatan evaluasi/ penilaian. }\end{array}$ \\
\hline
\end{tabular}

Menurut Sugiyono (2013) populasi adalah wilayah generalisasi yang terdiri atas objek atau subjek yang mempunyai kualitas dan karakteristik tertentu yang ditetapkan oleh peneliti untuk dipelajari dan kemudian ditarik kesimpulannya. Populasi berkaitan dengan data-data. Jika setiap manusia memberikan suatu data, maka ukuran atau banyaknya populasi akan sama dengan banyaknya manusia, maka yang dimaksud dengan populasi dalam penelitian ini adalah seluruh peserta didik kelas XI Program Studi IPS di SMA Negeri Kota Mojokerto tahun pelajaran 2015/2016 yang berjumlah 339 orang.Untuk menentukan jumlah sampel dari anggota populasi dalam penelitian ini memakai rumus slovin, berdasarkan perhitungan tersebut maka dalam penelitian ini penentuan jumlah sampel dari populasi yang ada yaitu sebanyak 184 sampel.Teknik pengambilan sampel dari populasi dalam penelitian ini ditentukan dengan menggunakan teknik Proposional sampling. 


\section{HASIL PENELITIAN DAN PEMBAHASAN}

\section{Hasil Penelitian}

1. Penyajian data Intelegensi

Data variabel Intelegensi dalam penelitian ini diambil dari hasil Tes IQ peserta didik kelas XI IPS SMA Negeri Kota Mojokerto yang telah dilaksanakan oleh sekolah masing-masing bekerja sama dengan Lembaga Psikologi Tjiptoning sebagai berikut:

\begin{tabular}{ccccc}
\hline \multirow{2}{*}{ No } & \multirow{2}{*}{ Skala Skor } & \multirow{2}{*}{ Tingkat Intelegensi } & \multicolumn{2}{c}{ Frekuensi } \\
\cline { 4 - 5 } & & F & \% \\
\hline 1 & $120-127$ & Superior(Sangat Cerdas) & 0 & 0 \\
\hline 2 & $111-119$ & High Average(Cerdas) & 67 & 36,4 \\
\hline 3 & $91-110$ & Average(Normal) & 117 & 63,6 \\
\hline 4 & $80-90$ & Low Average(Lambat) & 0 & 0 \\
\hline & Jumlah & 184 & 100 \\
\hline
\end{tabular}

Sumber: Data diolah (2016)

2. Penyajian data Motivasi Belajar

Variabel motivasi belajar $\left(\mathrm{X}_{2}\right)$ terdiri dari enam indikator yaitu adanya hasrat dan keinginan berhasil, adanya dorongan dan kebutuhan dalam belajar, adanya harapan dan cita-cita masa depan, adanya penghargaan dalam belajar, adanya kegiatan yang menarik dalam belajar dan adanya lingkungan belajar yang kondusif. Berikut ini adalah hasil jawaban responden per indikator yang dinyatakan dengan angka dalam tabel kerja sebagai berikut:

\begin{tabular}{|c|c|c|c|c|c|}
\hline \multirow{2}{*}{ Indikator } & \multicolumn{4}{|c|}{ Banyak Jawaban Responden } & \multirow{2}{*}{ Jumlah } \\
\hline & STS & TS & $\mathrm{S}$ & SS & \\
\hline $\begin{array}{l}\text { Indikator } 1 \text { Adanya Hasrat dan Keinginan } \\
\text { Berhasil }\end{array}$ & 2 & 18 & 197 & 151 & 368 \\
\hline Persentase & 0,54 & 4,90 & 53,53 & 41,03 & 100 \\
\hline $\begin{array}{l}\text { Indikator } 2 \text { Adanya Dorongan dan Kebutuhan } \\
\text { Dalam Belajar }\end{array}$ & 11 & 83 & 316 & 142 & 552 \\
\hline Persentase & 2 & 15 & 57,3 & 25,7 & 100 \\
\hline $\begin{array}{l}\text { Indikator } 3 \text { Adanya Harapan dan Cita-Cita Masa } \\
\text { Depan }\end{array}$ & 4 & 2 & 133 & 229 & 368 \\
\hline Persentase & 1,08 & 0,55 & 36,15 & 62,22 & 100 \\
\hline Indikator 4 Adanya Penghargaan Dalam Belajar & 10 & 22 & 263 & 257 & 552 \\
\hline Persentase & 1,81 & 4 & 47,64 & 46,55 & 100 \\
\hline $\begin{array}{l}\text { Indikator } 5 \text { Adanya Kegiatan Menarik Dalam } \\
\text { Belajar }\end{array}$ & 7 & 78 & 331 & 136 & 552 \\
\hline Persentase & 1,27 & 14,13 & 59,97 & 24,63 & 100 \\
\hline $\begin{array}{l}\text { Indikator } 6 \text { Adanya Lingkungan Belajar yang } \\
\text { Kondusif }\end{array}$ & 25 & 57 & 135 & 151 & 368 \\
\hline Persentase & 6,79 & 15,48 & 36,68 & 41,05 & 100 \\
\hline
\end{tabular}

Sumber: Data diolah (2016) 


\section{Penyajian data Minat Belajar}

Variabel minat belajar $\left(\mathrm{X}_{3}\right)$ terdiri dari lima indikator yaitu perasaan senang, perhatian dalam belajar, ketertarikan, kemauan untuk belajar, dan relevansi (manfaat dan fungsi mata pelajaran ekonomi). Berikut ini adalah hasil jawaban responden per indikator yang dinyatakan dengan angka dalam tabel kerja sebagai berikut:

\begin{tabular}{|c|c|c|c|c|c|}
\hline \multirow{2}{*}{ Indikator } & \multicolumn{4}{|c|}{ Banyak Jawaban Responden } & \multirow{2}{*}{ Jumlat } \\
\hline & STS & TS & $\mathrm{S}$ & SS & \\
\hline Indikator 1 Adanya Perasaan Senang & 3 & 67 & 366 & 116 & 552 \\
\hline Persentase & 0,55 & 12,14 & 66,30 & 21,01 & 100 \\
\hline Indikator 2 Adanya Perhatian Dalam Belajar & 5 & 114 & 304 & 129 & 552 \\
\hline Persentase & 0,9 & 20,66 & 55,07 & 23,37 & 100 \\
\hline Indikator 3 Adanya Ketertarikan & 3 & 78 & 291 & 180 & 552 \\
\hline Persentase & 0,55 & 14,13 & 52,72 & 32,60 & 100 \\
\hline Indikator 4 Adanya Kemauan Untuk Belajar & 28 & 171 & 275 & 78 & 552 \\
\hline Persentase & 5,07 & 30,98 & 49,82 & 14,13 & 100 \\
\hline \multirow[t]{2}{*}{ Indikator 5 Adanya Relevansi } & 5 & 4 & 263 & 280 & 552 \\
\hline & 1 & 0,72 & 47,6 & 50,64 & 100 \\
\hline
\end{tabular}

Sumber: Data diolah (2016)

4. Penyajian data Hasil Belajar

Berdasarkan hasil analisis untuk variabel hasil belajar ekonomi, data diperoleh dari nilai ulangan akhir semester (UAS) peserta didik kelas XI IPS SMA Negeri Kota Mojokerto tahun pelajaran 2015-2016. Dari jumlah 184 sampel terangkum dalam tabel sebagai berikut:

\begin{tabular}{cccrc}
\hline \multirow{2}{*}{ No } & \multirow{2}{*}{ Rentang } & \multirow{2}{*}{ Kriteria Grade } & \multicolumn{3}{c}{ Frekuensi } \\
\cline { 4 - 5 } & $91-100$ & (A) Amat Baik & 4 & $\%$ \\
\hline 1 & $75-90$ & (B) Baik & 147 & 2,10 \\
\hline 2 & $60-74$ & (C) Cukup & 27 & 79,9 \\
\hline 3 & $<59$ & (D) Kurang & 6 & 14,7 \\
\hline 4 & Jumlah & 184 & 100 \\
\hline
\end{tabular}

Sum ber: Data diolah (2016)

\section{Hasil Uji Asumsi Klasik\& Regresi Linier Berganda}

Dari hasil uji normalitas, nilai Kolmogorov Smirnov yang dihasilkan sebesar 1.166 dengan tingkat signifikan sebesar 0,132 . Tingkat signifikan yang dihasilkan tersebut jauh lebih besar dari 0,05 yang berarti residual mengikuti distribusi normal.

Dari hasil uji multikolinieritas untuk mengetahui apakah model regresi dalam penelitian ini ditemukan adanya korelasi diantar variabel bebasnya, maka diperoleh hasil bahwa seluruh variabel bebas $(\mathrm{X})$ yang digunakan dalam penelitian ini mempunyai nilai tolerance $>0,10$ dan nilai $\mathrm{VIF}<10$, maka dapat dikatakan bahwa antara variabel bebas tidak terjadi multikolinieritas atau antara variabel-variabel bebas tidak memiliki korelasi yang tinggi. 
Dari hasil uji heteroskesdastisitas menggunakan uji Geljser menunjukkan bahwa tingkat signifikan yang dihasilkan oleh variabel intelegensi $\left(\mathrm{X}_{1}\right)$, motivasi belajar $\left(\mathrm{X}_{2}\right)$, dan minat belajar $\left(\mathrm{X}_{3}\right)$ melebihi 0,05 maka dapat dikatakan bahwa persamaan regresi linier berganda yang digunakan bebas heteroskesdastisitas atau terdapat kesamaan varians dari residual satu pengamatan ke pengamatan yang lain.

Berdasarkan perhitungan analisis regresi linier berganda, maka dapat dibuat model persamaan regresi linear berganda sebagai berikut: $\mathrm{Y}=79.942+$ $0.121 \mathrm{X}_{1}+0.204 \mathrm{X}_{2}+0.115 \mathrm{X}_{3}+$ e. Berdasarkan model persamaan regresi linear berganda tersebut, maka dapat diartikan: 1) Nilai konstanta sama dengan 79.942. Artinya jika variabel ntelegensi $\left(\mathrm{X}_{1}\right)$, variabel motivasi belajar $\left(\mathrm{X}_{2}\right)$, dan variabel minat belajar $\left(\mathrm{X}_{3}\right)$ sama dengan nol, maka rata-rata hasil belajar ekonomi peserta didik (Y) sebesar 79.942 ; 2) Nilai koefisien regresi atau $b_{1}$ sama dengan +0.121 . Artinya jika variabel intelegensi $\left(\mathrm{X}_{1}\right)$ meningkat satu satuan, maka hasil belajar ekonomi akan naik sebesar 0.121. Tanda positif melambangkan adanya hubungan searah antara $\mathrm{X}_{1}$ dan $\mathrm{Y}$, sehingga apabila $\mathrm{X}_{1}$ meningkat maka akan meningkatkan $\mathrm{Y}$, dengan asumsi variabel bebas lainnya adalah nol atau konstan; 3) Nilai koefisien regresi atau b2 sama dengan +0.204 . Artinya jika variabel motivasi belajar $\left(\mathrm{X}_{2}\right)$ meningkat satu satuan, maka hasil belajar ekonomi akan meningkat sebesar 0.204. Tanda positif melambangkan adanya hubungan searah antara $\mathrm{X}_{2}$ dan $\mathrm{Y}$, sehingga apabila $\mathrm{X}_{2}$ meningkat maka akan meningkatkan $\mathrm{Y}$, dengan asumsi variabel bebas lainnya adalah nol atau konstan; 4) Nilai koefisien regresi atau b3 sama dengan +0.115 . Artinya jika variabel minat belajar $\left(\mathrm{X}_{3}\right)$ meningkat satu satuan, maka hasil belajar ekonomi akan meningkat sebesar 0.115 . Tanda positif melambangkan adanya hubungan searah antara $\mathrm{X}_{2}$ dan $\mathrm{Y}$, sehingga apabila $\mathrm{X}_{2}$ meningkat maka akan meningkatkan $\mathrm{Y}$, dengan asumsi variabel bebas lainnya adalah nol atau konstan.

Berdasarkan hasil koefisien determinasi berganda $\left(\mathrm{R}^{2}\right)$ sebesar 0,195 ,artinya $19,5 \%$ dari perubahan variabel hasil belajar pada mata pelajaran ekonomi kelas XI IPS SMA Negeri Kota Mojokerto dipengaruhi oleh intelegensi, motivasi belajar, dan minat belajar sedangkan sisanya 80,5\% dipengaruhi oleh faktor-faktor yang tidak diikutsertakan dalam penelitian ini.

\section{Hasil Uji Hipotesis}

Berdasarkan hasil uji hipotesis dengan menggunakan uji t dan uji $\mathrm{F}$, maka diperoleh hasil sebagai berikut: 1) Intelegensi $\left(\mathrm{X}_{1}\right)$ mempunyai nilai thitung $3.812>$ tabel 1.9732 dengan tingkat signifikansi sebesar $0,000<0,05(\alpha)$, maka H0 ditolak dan Ha diterima, yang artinya variabel intelegensi berpengaruh signifikan secara parsial terhadap hasil belajar ekonomi; 2) Motivasi belajar $\left(\mathrm{X}_{2}\right)$ mempunyai nilai thitung $2.439>$ tabel 1.9732 dengan tingkat signifikansi sebesar $0,017<0,05(\alpha)$, maka $\mathrm{H} 0$ ditolak dan Ha diterima, yang artinya variabel motivasi belajar berpengaruh signifikan secara parsial terhadap hasil belajar ekonomi; 3) Minat belajar ( $\left.\mathrm{X}_{3}\right)$ mempunyai nilai thitung $2.863>$ tabel 1.9732 tingkat signifikansi sebesar $0,004<0,05(\alpha)$, maka $\mathrm{H} 0$ ditolak dan Ha diterima, yang artinya variabel minat belajar berpengaruh signifikan secara parsial terhadap hasil belajar ekonomi; 4) Nilai probabilitas sebesar $0.000<$ nilai alpha sebesar 0.05 , maka dapat disimpulkan bahwa $\mathrm{H}_{0}$ ditolak dan $\mathrm{H}_{\mathrm{a}}$ 
diterima yang artinya intelegensi, motivasi belajar, dan minat belajar secara simultan atau bersama-sama berpengaruh signifikan terhadap hasil belajar ekonomi.

\section{Pembahasan}

\section{Pengaruh Intelegensi Terhadap Hasil Belajar Ekonomi}

Berdasarkan hasil uji t antara variabel intelegensi terhadap hasil belajar ekonomi kelas XI IPS SMA Negeri Kota Mojokerto diketahui bahwa keduanya memiliki hubungan yang signifikan, artinya intelegensi peserta didik kelas XI IPS SMA Negeri Kota Mojokerto mampu menjelaskan perubahan dari hasil belajar ekonominya. Hasil penelitian ini juga sesuai dengan hasil penelitian-penelitian sebelumnya antara lain hasil penelitian Mustachfidoh (2013), Sudiarta (2013), Kaur (2014), Sala (2004), dan Babelan (2010) yang mengatakan bahwa ada pengaruh signifikan intelegensi terhadap hasil belajar peserta didik.

Hasil studi observasi awal maupun berdasarkan hasil penyajian data pada bab 4 tentang hasil belajar ekonomi peserta didik kelas XI IPS SMA Negeri Kota Mojokerto, dapat diketahui bahwa beberapa peserta didik memperoleh hasil belajar ekonomi yang kurang memuaskan, yaitu dibawah nilai Kriteria Ketuntasan Minimun (KKM) yang telah ditetapkan oleh SMA Negeri Kota Mojokerto yaitu 75, sehingga dapat diketahui bahwa peserta didik kelas XI IPS SMA Negeri Kota Mojokerto yang memiliki kriteria intelegensi yang baik yaitu berada pada kriteria rata-rata dan kriteria diatas rata-rata ternyata beberapa peserta didiknya memiliki hasil belajar ekonomi yang kurang memuaskan.

Intelegensi peserta didik kelas XI IPS SMA Negeri Kota Mojokerto dengan kriteria rata-rata dan diatas rata-rata ternyata bukanlah faktor utama yang mampu menjamin peserta didik memiliki hasil belajar ekonomi yang optimal, hal ini sesuai dengan pernyataan Azwar (2008) bahwa penentu keberhasilan peserta didik dalam bidang akademisnya tidak hanya dapat dilihat dari aspek intelegensi saja, tapi masih ada faktor-faktor pendukung lainnya yang mampu membuat peserta didik meraih hasil belajar yang optimal.

Hal yang perlu dipahami oleh peserta didik, guru, orang tua, dan masyarakat dilingkungan sekitar peserta didik adalah bahwa setiap individu yang dalam penelitian ini adalah peserta didik, memiliki tingkat intelegensi yang berbeda-beda sehingga mengakibatkan perbedaan kemampuan peserta didik dalam memecahkan suatu persoalan yang mereka hadapi. Kenyataan menunjukkan bahwa setiap peserta didik memiliki tingkat inteligensi yang berbeda-beda dan perbedaan tersebut yang akan memberikan warna selama kegiatan belajar mengajar berlangsung, sehingga dibutuhkan pendekatan secara personal antara peserta didik dengan guru dan orang tua untuk mengetahui faktor-faktor lain diluar intelegensi yang mampu membuat peserta didik meraih hasil belajar yang optimal.

\section{Pengaruh Motivasi Belajar Terhadap Hasil Belajar Ekonomi}

Berdasarkan data tentang hasil belajar ekonomi kelas XI IPS SMA

Negeri Kota Mojokerto dimana terdapat beberapa peserta didik yang memperoleh nilai dibawah Kriteria Ketuntasan Minimum (KKM), menurut 
peneliti hal ini disebabkan oleh beberapa peserta didik yang kurang atau tidak memiliki motivasi belajar, sebagaimana disajikan dalam deskripsi variabel motivasi belajar diketahui bahwa terdapat beberapa peserta didik yang menjawab tidak setuju atas pernyataan-pernyataan yang telah disampaikan yang artinya mereka kurang memiliki atau bahkan tidak memiliki motivasi belajar.

Menurut Uno (2011) motivasi sangat berperan dalam belajar, adanya motivasi belajar membuat peserta didik akan menjadi tekun dalam belajar. Peserta didik yang selama proses belajar mempunyai motivasi belajar yang tinggi maka akan tekun dalam belajar sehingga akan berhasil dalam belajar. Sebaliknya, apabila motivasi peserta didik rendah maka peserta didik akan tidak tahan lama belajar dan mudah merasakan bosan serta mudah tergoda untuk mengerjakan hal yang lain. Tingginya motivasi dalam belajar akan berpengaruh pada tingginya hasil belajar ekonomi, sebaliknya jika motivasi belajar rendah, maka akan berpengaruh pada rendahnya hasil belajar ekonomi peserta didik.

Motivasi belajar merupakan faktor utama dalam kegiatan belajar karena akan menimbulkan, mendasari, dan menggerakan perbuatan belajar. Berdasarkan hasil penelitian melalui angket dan hasil wawancara dengan guru mata pelajaran ekonomi diketahui bahwa kebanyakan peserta didik yang besar motivasinya akan giat berusaha,tampak gagah,tidak mau menyerah, serta giat membaca untuk meningkatkan hasil belajar serta memecahkan masalah yang dihadapinya. Sebaliknya mereka yang memiliki motivasi rendah, tampak acuh tak acuh, mudah putus asa, perhatiannya tidak tertuju pada pembelajaran yang akibatnya peserta didik akan mengalami kesulitan belajar.

Dengan mempelajari tentang indikator-indikator motivasi belajar maka akan ditemukan mengapa peserta didik belajar, karena motivasi pada diri peserta didik tidak dapat diamati secara langsung, yang dapat diamati adalah manifestasi dari motivasi belajar itu dalam bentuk tingkah laku yang nampak pada peserta didikyang setidaknya akan menjadi mendekati kebenaran apa yang menjadi motivasi belajar peserta didik. Mengingat pentingnya motivasi belajar dalam meningkatkan hasil belajar ekonomi maka baik peserta didik dan guru sebagai mediator dalam proses pembelajaran harus selalu ingat betapa pentingnya memberikan alasan-alasan kepada peserta didik mengapa mereka harus belajar dengan sungguh-sungguh dan berusaha untuk berprestasi dengan sebaik-baiknya.

\section{Pengaruh Minat Belajar Terhadap Hasil Belajar Ekonomi}

Berdasarkan hasil analisis data statistik dengan menggunakan uji $\mathrm{t}$ antara variabel minat belajar terhadap hasil belajar ekonomi maka diketahui bahwa terdapat hubungan yang positif sehingga memiliki pengaruh yang signifikan, artinya minat belajar peserta didik kelas XI IPS SMA Negeri Kota Mojokerto mampu menjelaskan perubahan dari hasil belajar ekonominya. 
Data tentang hasil belajar ekonomi kelas XI IPS SMA Negeri Kota Mojokerto dimana terdapat beberapa peserta didik yang memperoleh nilai dibawah Kriteria Ketuntasan Minimum (KKM), menurut peneliti hal ini disebabkan oleh beberapa peserta didik yang kurang atau tidak memiliki minat belajar, sebagaimana disajikan dalam deskripsi variabel minat belajar diketahui bahwa terdapat beberapa peserta didik yang menjawab tidak setuju atas pernyataan-pernyataan yang telah disampaikan yang artinya mereka kurang memiliki atau bahkan tidak memiliki minat belajar.

Menurut Djamarah (2002) minat belajar besar pengaruhnya terhadap aktivitas belajar, peserta didik yang memiliki minat belajar akan belajar dengan sungguh-sungguh karena ada daya tarik baginya, sehingga hasil belajar yang diperoleh dapat optimal. Hal tersebut sesuai dengan pernyataan Hamalik (2008) bahwa belajar dengan minat akan mendorong peserta didik belajar lebih baik daripada belajar tanpa minat. Minat yang besar terhadap sesuatu merupakan modal untuk memperoleh tujuan yang diminati. Jadi, dengan adanya minat yang dimiliki peserta didik dapat mempengaruhi pencapaian hasil belajarnya.

Berdasarkan hasil penelitian ini diketahui bahwa rata-rata jawaban angket minat belajar peserta didik kelas XI IPS SMA Negeri Kota Mojokerto dapat dikategorikan baik, namun hasil ini tidak diimbangi dengan hasil belajar ekonomi peserta didik, dimana beberapa peserta didik mendapatkan hasil belajar dibawah kriteria ketuntasan minimum 75, sehingga permasalahan inilah yang membutuhkan penanganan khusus. Peserta didik yang memiliki minat belajar rendah harus dipacu supaya mereka dapat memiliki minat belajar yang tinggi. Menurut peneliti berdasarkan hasil observasi awal dan hasil penelitian terdapat kesenjangan, dimana pada studi observasi awal guru ekonomi mengatakan bahwa minat belajar peserta didik kurang baik sedangkan hasil penelitian ini menunjukkan bahwa minat belajar peserta didik kelas XI IPS tergolong baik, sehingga dalam hal ini baik peserta didik maupun guru dapat melakukan evaluasi untuk mengetahui hal-hal apa saja yang bisa meningkatkan minat belajar peserta didik agar peserta didik dapat memperoleh hasil belajar yang lebih baik dan mencapaikriteria ketuntasan minimum atau bahkan diatas kriteria ketuntasan minimum.

4. Pengaruh Intelegensi, Motivasi Belajar, Minat Belajar Terhadap Hasil Belajar Ekonomi

Berdasarkan hasil uji $\mathrm{F}$ dalam penelitian ini menunjukkan bahwa intelegensi, motivasi belajar, dan minat belajar berpengaruh secara simultan terhadap hasil belajar ekonomi kelas XI IPS di SMA Negeri Kota Mojokerto, artinya intelegensi, motivasi belajar, dan minat belajar secara bersama-sama mampu menjelaskan perubahan dari hasil belajar ekonomi kelas XI IPS di SMA Negeri Kota Mojokerto.

Dalam penelitian ini diketahui bahwa variabel yang paling besar mempengaruhi hasil belajar ekonomi kelas XI IPS di SMA Negeri Kota Mojokerto adalah motivasi belajar, berdasarkan hasil pengamatan dari berbagai hasil penelitian tentang motivasi belajar selalu menyimpulkan bahwa motivasi belajar mempengaruhi hasil belajar peserta didik, bahkan tinggi rendahnya motivasi belajar peserta didik selalu dijadikan indikator utama baik buruknya 
hasil belajar seorang peserta didik. Hal ini dikarenakan motivasi belajar merupakan suatu perubahan tingkah laku dalam diri peserta didik yang menimbulkan proses belajar individu yang berinteraksi langsung dengan objek belajar.

Setelah motivasi belajar, variabel kedua yang besar pengaruhnya terhadap hasil belajar ekonomi kelas XI IPS di SMA Negeri Kota Mojokerto adalah intelegensi, sehingga disini dapat dikatakan bahwa input peserta didik yang ada di SMA Negeri Kota Mojokerto sudah sangat baik hal ini terbukti dari intelegensi peserta didik yang dikategorikan rata-rata dan diatas rata-rata. Namun seperti yang sudah disampaikan pada kajian pustaka maupun pada diskusi hasil penelitian intelegensi terhadap hasil belajar yang mengatakan bahwa intelegensi bukan merupakan faktor penentu keberhasilan peserta didik dalam meraih hasil belajar yang tinggi. Intelegensi peserta didik yang tinggi memang merupakan salah satu faktor yang mempengaruhi hasil belajar peserta didik, namun apabila intelegensi tersebut tidak diimbangi dengan faktor-faktor pendukung yang lain, maka akan sia-sia. Hasil penelitian ini sesuai dengan teori yang dikemukakan oleh Syah (2006) bahwa tingkat kecerdasan atau intelegensi (IQ) peserta didik sangat menentukan tingkat keberhasilan belajar peserta didik. Ini bermakna, semakin tinggi kemampuan intelegensi seorang peserta didik, maka semakin besar peluangnya untuk meraih sukses, dan sebaliknya semakin rendah kemampuan intelegensi seorang peserta didik maka semakin kecil peluangnya untuk memperoleh sukses. Terdapat kontribusi positif antara intelegensi (kecerdasan) terhadap hasil belajar ekonomi peserta didik.

Variabel terakhir yang berkontribusi terhadap hasil belajar ekonomi kelas XI IPS SMA Negeri Kota Mojokerto adalah minat belajar, berdasarkan hasil analisis data diketahui bahwa minat belajar memiliki kontribusi paling kecil dalam mempengaruhi hasil belajar ekonomi bila dibandingkan dengan motivasi belajar dan intelegensi peserta didik. Hal ini dikarenakan minat belajar ketika dikaitkan dengan aktivitas belajar merupakan salah satu alat motivasi atau dasar bagi peserta didik untuk melakukan aktivitas belajar. Tanpa adanya minat dalam diri peserta didik terhadap hal yang akan dipelajari, maka peserta didik akan ragu-ragu untuk belajar sehingga tidak menghasilkan hasil belajar ekonomi yang optimal atau sepertinya yang diinginkan. Minat belajar pada dasarnya adalah penerimaan akan adanya suatu hubungan antara diri sendiri dengan diluar diri sendiri. Peserta didik yang menaruh pada minat belajar akan menerima materi yang telah disampaikan oleh gurunya dan mencari berbagai litelatur pelajaran tanpa adanya paksaan dari siapapun.

Berdasarkan penjabaran hasil diskusi penelitian tentang pengaruh intelegensi, motivasi belajar, dan minat belajar maka dapat diambil kesimpulan bahwa ketiga variabel tersebut memiliki kontribusi terhadap hasil belajar ekonomi peserta didik kelas XI IPS SMA Negeri di Kota Mojokerto. Sehingga selanjutnya baik peserta didik, guru, orang tua, dan masyarakat dapat mengetahui tentang pentingnya faktor-faktor yang mempengaruhi hasil belajar peserta didik. Ketika hasil belajar peserta didik baik maka tujuan dari pendidikan nasional kita akan tercapai. 


\section{KESIMPULAN}

Berdasarkan hasil penelitian dan analisis data, maka dapat dikemukakan kesimpulan sebagai berikut: (1) Intelegensi berpengaruh terhadap hasil belajar ekonomi kelas XI IPS di SMA Negeri Kota Mojokerto. Hal ini membuktikan bahwa intelegensi peserta didik yang meliputi pemahaman, penalaran, kemampuan berhitung, kemampuan mekanik, logika abstrak, dan logika verbal merupakan faktor pendorong dalam kegiatan belajar dan akan berdampak pada hasil belajar ekonomi peserta didik, meskipun intelegensi peserta didik bukan merupakan satu-satunya faktor yang menentukan tinggi rendahnya hasil belajar; (2) Motivasi belajar berpengaruh terhadap hasil belajar ekonomi kelas XI IPS di SMA Negeri Kota Mojokerto. Hal ini membuktikan bahwa ketika peserta didik memiliki hasrat keinginan berhasil, memiliki dorongan dalam belajar, memiliki citacita masa depan, mendapatkan penghargaan dalam belajar, menemukan kegiatan yang menarik ketika belajar, dan berada lingkungan belajar yang kondusif, maka motivasi belajar merupakanfaktor pendorong bagi peserta didik untuk melakukan kegiatan belajar yang akan berdampak pada hasil belajar ekonomi peserta didik; (3) Minat belajar berpengaruh terhadap hasil belajar ekonomi kelas XI IPS di SMA Negeri Kota Mojokerto. Hal ini membuktikan bahwa ketika peserta didik dalam proses belajar memiliki perasaan senang, perhatian, memiliki rasa ketertarikan, memiliki kemauan besar untuk belajar, dan menyadari akan manfaat dan fungsi mata pelajaran yang sedang dipelajari, maka minat belajar merupakan pendorong untuk melakukan kegiatan belajar yang akan berdampak pada hasil belajar ekonomi peserta didik; (4) Berdasarkan hasil perhitungan pada analisis data statistik dapat diketahui bahwa intelegensi, motivasi belajar, dan minat belajar secara bersama-sama berpengaruh signifikan terhadap hasil belajar ekonomi kelas XI IPS di SMA Negeri Kota Mojokerto. Motivasi belajar peserta didik memiliki kontribusi yang paling besar dalam pengaruhnya terhadap hasil belajar jika dibandingkan dengan intelegensi yang menempati urutan kedua, dan minat belajar yang menempati urutan terakhir.

\section{DAFTAR RUJUKAN}

Anastasi, A., \& Urbani, S. (2007). Test Psikologi (Psyhological Testing). Jakarta: PT. Prehanllindo.

Azwar, S. (2008). Pengantar PsikologiIntelegensi. Yogyakarta: Pustaka Pelajar.

Babelan, A. Z. (2010). The Role of Emotional Intelligence in Predicting Students Academic Achievement in Distance Education System. Iran Edcation and Educational Psychology. 2(2), 1154-1157.

Departemen Pendidikan Nasional. (2003). Undang-Undang Nomor 20 Tahun 2003, Tentang Sistem Pendidikan Nasional. Jakarta: Depdiknas.

Departemen Pendidikan Nasional. (2007). Peraturan Menteri Pendidikan NasionalNomor 19 Tahun 2007, tentang Standar Pengelolaan Pendidikan Oleh Satuan Pendidikan Dasar dan Menengah. Jakarta: Depdiknas. 
Djamarah, S.B. (2002). Psikologi belajar. Jakarta: PT Rineka Cipta.

Hamalik, O. (2008). Proses Belajar Mengajar. Jakarta: Bumi Aksara.

Ijaz, A. T. (2012). Role of Intelligence and Creativity in the academic achievement of student. International Journal of Physical and Social Sciences. 2(7), 1-10.

Kasiram, M. (2008). Metode Penelitian Kuantitatif-Kualitatif. Malang: UINMalang Press.

Kaur, M. (2014). Comparative Analysis Of Learning Styles Of Secondary School Students By Gender and Grade. International Journal of Advance Research in Education, Technology, \& Management. 2(3), 212-215.

Mustachfidoh, I. B. (2013). Pengaruh Model Pembelajaran Inkuiri Terhadap Hasil Belajar Biologi Ditinjau Dari Inteligensi Siswa SMA Negeri 1 Srono. E- Journal Program Pascasarjana Universitas Pendidikan Ganesha Program Studi Pendidikan Sains. 3(1), 23-32.

Safari. (2005). Penulisan Butir Soal Berdasarkan Penilaian Berbasis Kompetensi. Jakarta:APSI Pusat.

Sala, F. (2004). Do Programs Designed to Increase Emotional Intelligence at work. Boston. Journal of management Development. 21(1), 83-91.

Slameto. (2010). Belajar dan Faktor-Faktor yang Mempengaruhinya. Jakarta: PT. RinekaCipta.

Sudiarta, N., \& Marhaeni, AAIN., \& Suhandana, A. (2013). Kontribusi Tingkat Intelegensi, Nilai Ujian Nasional Bahasa Inggris SMP, Minat Belajar Bahasa Inggris Terhadap Prestasi Belajar Bahasa Inggris Siswa Kelas X SMA Negeri 2 AmlapuraTahun Pelajaran 2012/2013. E-Jurnal Program Pascasarjana Universitas Pendidikan Ganesha Program Administrasi Pendidikan.4(1), 21-29.

Sudjana, N. (2013). Dasar Dasar Proses Belajar Mengajar. Bandung: Sinar Baru Aglesindo.

Sugiyono. (2013). Metode Penelitian Kuantitatif Kualitatif dan $R \& B$. Bandung: Alfabeta.

Syah, M. (2006). Psikologi belajar. Jakarta: PT Raja Grafindo Persada.

Uno, H. B. (2011). Teori Motivasi dan Pengukurannya. Jakarta: Bumi Aksara

Wayan. I Dwija. (2008). Hubungan Antara Konsep Diri, Motivasi Berprestasi, dan Perhatian Orang Tua Dengan Hasil Siswa Kelas II Sekolah Menengah Atas Unggulan di Kota Amlapura. Jurnal Pendidikan dan Pengajaran Undhiksa. 41(1), 215-250. 